\title{
Electoral Rules, Women's Representation and the Qualification of Politicians
}

\author{
Paola Profeta*
}

Eleanor Florence Woodhouse $\mathrm{i}^{\dagger+}$

\begin{abstract}
Proportional electoral rules are associated with more substantial women's representation than majoritarian ones. To provide causal evidence that electoral rules affect women's representation and the qualification of politicians, we collect panel data on the universe of Italian politicians from all levels of government over the period 1987-2013 and analyse an Italian reform which, in 2005, changed the electoral rule for national elections from (mostly) majoritarian to proportional, but did not affect subnational level elections. We find that this reform increased the number of women elected by $5 \%$, while not decreasing the overall qualification levels of politicians, measured by the level of education and political experience. We provide evidence that the highest qualification women are not elected and that the overall qualification of elected politicians could have increased (rather than remain constant) if the best women candidates had been elected.
\end{abstract}

Keywords: Electoral Reforms; Women's Political Representation; Difference-in-Differences. 


\section{Introduction}

Women are still under-represented on the political stage across the globe. According to the Inter-Parliamentary Union database, only 11 countries out of 193 have more than $40 \%$ of women in their national parliaments and 121 countries have less than $25 \%$ women's representation (Inter-Parliamentary Union, 2017). Not a single OECD country has yet reached gender parity in its national parliament: the highest is Mexico with $48.2 \%$ of women and the OECD average remains at 30.1\% (OECD, 2019). However the presence of women in politics matters, not only for descriptive representation, but also for substantive representation, especially in terms of effectively voicing 'women's interests' and influencing policy outcomes (see a recent review in Hessami and Lopes da Fonseca (2020)). Existing research has linked the under-representation of women to voter bias (Fréchette et al., 2008; Dolan, 2014; Dolan and Lynch, 2016; Hayes and Lawless, 2016; Dolan, 2018; Le Barbanchon and Sauvagnat, forthcoming), party bias (Norris and Lovenduski, 1993; Fox and Lawless, 2010; Lawless and Fox, 2010), and political competition (Folke and Rickne, 2016).

Electoral rules have also been shown to matter, mainly because proportional systems tend to favour the election of women with respect to majoritarian ones (Rule, 1987). In parallel, electoral rules have been shown to influence the qualification of elected politicians:

${ }^{*}$ Bocconi University

†University College London

‡We thank Vincenzo Galasso and Tommaso Nannicini for providing us with detailed individual data on national politicians as well as polling data and voting margins for specific elections at the national level, Michele Castiglioni for aggregate data on national candidate numbers, and Armando Miano for individual data on the 2008 national election. We thank Johanna Rickne, Olle Folke, Anthony Bertelli, Vincenzo Galasso, Massimo Morelli, Tommaso Nannicini, Michele Castiglioni and Anna Raute for useful comments. We thank participants at EPCS 2018, SISP 2018, EPCA 2018, the 2018 Dondena Political Economy workshop, the 2019 Political Economy Workshop in Konstanz, and EGEN 2019. Authors' names are listed alphabetically. Any remaining errors are our own. 
in majoritarian systems, tougher political races are associated with higher qualification levels of elected politicians, measured by the level of education, as opposed to proportional systems (Galasso and Nannicini, 2011). Proportional systems seem unable to elect the best candidates.

However, as women's representation is positively related to the qualification of politicians (Baltrunaite et al., 2014), because women candidates have been found, overwhelmingly, to be as or more qualified than their male counterparts (Murray, 2010, 2012; Franceschet and Piscopo, 2013; O’Brien and Rickne, 2016; Barnes and Holman, 2019), their increased representation in proportional systems may counterbalance the negative selection effect associated with proportional rules. Thus, the overall qualification levels of politicians may remain equal or even increase with respect to those characterising a majoritarian system.

To provide evidence of these effects, we assemble data on the universe of Italian politicians from all levels of government - national, regional, provincial, municipal - over the period 1987-2013. We exploit the existence of different electoral rules across levels of government to form our research design: in 2005, a reform was introduced which changed the electoral rule for national elections from a mixed-member system - whereby $75 \%$ of representatives were elected via a majoritarian system and $25 \%$ via a proportional system - to a closed list proportional rule with a majority bonus. Since the reform applies only to national elections and not to subnational ones, we use a Difference-in-Differences (hereafter, DiD) approach to show that the proportional electoral rule increases women's representation at the national level. The effect is substantial: the proportional rule increases the share of elected women by about $5 \%$. Our rich dataset allows us to include controls for individual characteristics that may boost one's likelihood of being elected - 
such as education level, years of subnational political experience, and party affiliation and to perform numerous robustness analyses.

Using a simpler research design, we also show that the qualification of politicians (measured by educational level and subnational experience) elected to national office following the proportional reform remains stable or, if anything, slightly increases. Finally, for the 2013 national election we provide evidence of negative selection for women (but not for men): the women elected under the proportional system are not those with the highest qualification levels among the women candidates. The overall qualification of politicians could actually have increased had the best women candidates been selected.

Our results may be related to culture and gender norms. An additional interesting finding arises when we exploit heterogeneity across Italian regions with respect to their level of gender culture: the reform introducing the proportional system has a stronger effect on women's representation in more gender traditional regions. Moreover, these are also the regions which show a stronger divergence between the qualification levels of non-elected and elected women politicians (exploiting data on the 2013 national election).

This paper builds on several strands of the existing literature: women's representation in politics (see, among others, Norris (1985); Fox and Lawless (2010); Folke and Rickne (2016); Hessami and Lopes da Fonseca (2020)), the selection of politicians (Besley et al., 2017; Baltrunaite et al., 2014; Galasso and Nannicini, 2011, 2015), and the role of electoral rules (Norris, 2006). The paper makes the following contributions. First, it develops an original within-country analysis to appropriately identify the causal effects of electoral rules on women's political representation. Most of the existing evidence on the favourable conditions of proportional electoral rules for women's representation are cross-national (see 
Section 2) or compare pre- and post-electoral levels of women's representation without a within-country counterfactual (Roberts et al., 2013). Moreover, apart from few exceptions (Cayer and Sigelman, 1980; Bratton and Ray, 2002; Golder et al., 2017), most of the existing studies have concentrated solely on national governments. However, this is only the tip of the iceberg. Subnational levels of government are crucial for how power gets translated into action. Second, we shed light on the possible quantity-quality trade-offs associated with electoral rules and women's representation. While the positive effect of quotas and affirmative action policies on the qualification of politicians has been investigated extensively, the role of electoral reforms has not been explored yet.

Our analysis focuses on Italy, a country characterised by low women's political representation. Italy has experienced several reforms in electoral rules, which affect differently its various levels of government, thus providing an opportunity to exploit within-country variation in electoral systems over time.

\section{Electoral Rules and Women in Politics}

There is consensus in the literature on political representation that countries applying proportional rules are associated with higher numbers of women in their national parliaments than those with majoritarian rules (Norris, 1985; Rule, 1981, 1987; Rule and Zimmerman, 1994; Rule, 1994; Matland and Studlar, 1996; Vengroff et al., 2003; Kittilson and SchwindtBayer, 2012; Thames, 2017). Indeed, in 2016 women won $23.9 \%$ of seats in chambers elected by proportional rule and $24.4 \%$ in those using either proportional or mixed electoral systems, compared to $15 \%$ of seats in chambers elected through a majority rule and $22.2 \%$ where the chamber is appointed or indirectly elected (Inter-Parliamentary Union, 2016). 
Proportional systems are argued to promote greater representation of women through several mechanisms. First, in proportional systems a balanced and diverse ticket is preferable in order to appeal to a wider spectrum of voters, whereas in majoritarian systems the optimal strategy is to choose the strongest candidate with the broadest appeal, experience, or vote base. As Norris (1985)[p.99] puts it, given that in majoritarian settings more emphasis is placed on individuals than on parties, "candidates' abilities, experience, policies, and personal characteristics are scrutinised, their sex may play a more important role than under proportional arrangements". Second, fewer incumbents are re-elected under proportional rules (Norris, 1985, 2006), which should favour women who have historically been under-represented in most political contexts. Third, proportional systems have consistently higher district magnitudes (and higher party magnitudes), so parties can pull from deeper in their lists, which scholars have argued increases the chances of women being elected (Rule, 1987; Norris, 2006). Fourth, proportional representation rules allow for features such as closed lists which encourage - or even force in the case of zipper systems - parties to include women in their lists. However, the evidence on how the nature of the list - open or closed - used in proportional elections affects women's representation is mixed. Early work argued that open lists were preferable for women candidates (Shugart, 1994; Rule and Shugart, 1995) as voters can express a preference for a particular candidate and move them higher or lower on the list, thus preventing parties from holding women back by putting them low on the list. Open lists, however, tend to lead to the cultivation of the personal vote (Carey and Shugart, 1995) which can hinder women in the presence of cultural bias against them (Larserud and Taphorn, 2007; Valdini, 2013; Buitrago and Aroca, 2017). Moreover, Hessami and Baskaran (2019) 
show that the relatively weak performance of female candidates in the context of open lists is due to voters harbouring anti-female biases when they have not been exposed to female politicians before. ${ }^{1}$ Finally, the nature of a district itself has been found to affect women's representation, with multi-member districts being found to favour higher women's representation (King, 2002) with respect to single districts. In sum, not all proportional systems are equal when it comes to women's representation.

Electoral rules also matter for the qualification of politicians. Majoritarian elections imply a head-to-head race which has been shown to imply a higher qualification level of elected politicians with respect to proportional ones (Galasso and Nannicini, 2011). The role of electoral rules on the qualification of male and female politicians is theoretically less clear: on the one hand politicians elected under proportional systems tend to be more qualified, on the other hand more women are elected with a proportional system, and women tend to be more qualified than men (Besley et al., 2017; Baltrunaite et al., 2014).

\section{The Italian Electoral System}

The Italian Parliament is composed of the House (Camera) and the Senate (Senato). Italy has experienced several major electoral reforms over the years. From 1946-1993 deputies were elected under an open list proportional system with 32 districts for the House and 21 for the Senate. Following the 1993 Mattarellum reform, deputies were elected via a mixed methods system with two tiers (25\% closed-list proportional with a $4 \%$ vote threshold and $75 \%$ single round majoritarian with 475 single-member districts, hereafter SMDs). The electoral rules were changed again in 2005 with the Legge Calderoli or Porcellum reform,

\footnotetext{
${ }^{1}$ Open versus closed lists may also affect the quality of candidates, see Hangartner et al. (2019).
} 
returning to a proportional system, but this time with closed lists and 27 districts for the House and 20 for the Senate. This system entailed a majority bonus for the winning coalition of party lists. Most recently, the Rosatellum passed in 2017.

We focus on the 2005 Porcellum reform. This reform was not intended to influence women's representation, the reformers were more interested in the balance of power between parties. The debate around electoral reform at the time centred on party politics and which parties were likely to benefit most from the reform. The 2005 Italian reform differs from the 1993 one, where gender quotas were integrated into the reform and a significant part of the debate focused on them.

Timeline 1 summarises the timing of national electoral reforms in Italy. We consider national elections held in 1987, 1992, 1994, 1996, 2001, 2006, 2008 and 2013. The number of parliamentarians and senators has remained fixed for this period: 630 parliamentarians and 315 senators.

Timeline 1. National Electoral Reforms in Italy, 1993-2017

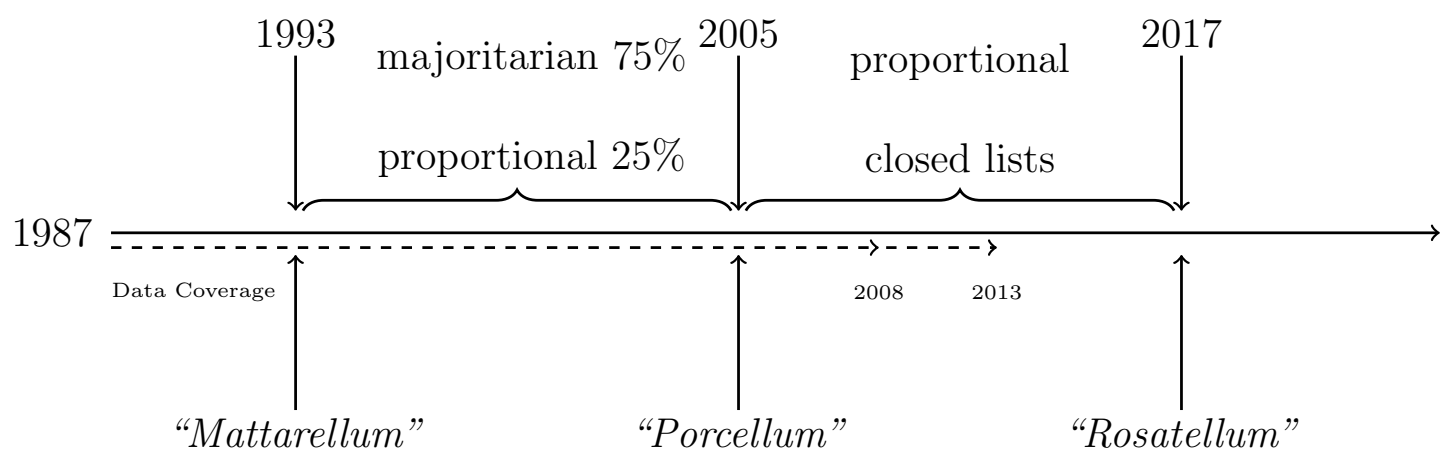

At subnational level, Italy is organised in 20 regions, 97 provinces and 7,971 municipalities. Timeline 2 shows the subnational electoral rules in place during the time period under consideration. The regional elections during this period were mostly governed by (versions of) the 1995 Legge Tatarella, which was mixed, with $80 \%$ of the seats being assigned via 
an open list proportional rule and $20 \%$ via a majoritarian rule. ${ }^{2}$

The provincial and municipal elections, on the other hand, were governed by Law 81/1993. The electoral rule here was also proportional, but the 1993 law established that mayors were to be directly elected by their own constituents and instigated a majoritarian mechanism (assigning $60 \%$ of available seats to the winning coalition). ${ }^{3}$

\section{Timeline 2. Subnational Electoral Rules in Italy, 1993-2017}



Tatarella - PR

\section{Data}

To assemble our unique dataset, we combine various data sources and we manually collect additional information when missing. Starting from politicians at subnational levels of government, we collect the name, date of birth, gender, education level, profession, district of election and political role of all elected politicians for the years 1987-2013 from the

\footnotetext{
${ }^{2}$ Panachage was permitted, so voters could distribute their votes to a candidate for the presidency and a list that was not the one he/she was associated with. The law also had mechanisms to protect minorities in case of a landslide win for a single list and to ensure some stability of governance in case of a split election.
}

${ }^{3}$ See Section 1 of the Appendix for more information. 
municipal, provincial and regional levels of government. These data are provided by the Ministry of Internal Affairs (Ministero dell'Interno) and include all mayors, councillors, executive officers and presidents for the aforementioned subnational levels of government. The data are provided in a sparse way and separately for the different levels of government, so we had to make a concerted effort to collect, assemble and render them all usable (this included undertaking a data-scraping exercise to obtain data points that were missing from the national elections of 2008 and 2013, in particular). Figure 1 shows that women's representation has increased significantly in Italy over the years, but remains overall at just over $20 \%$ at its highest point in our sample. Figure 2 shows that women political representation at subnational levels is very low and varies significantly from level to level.

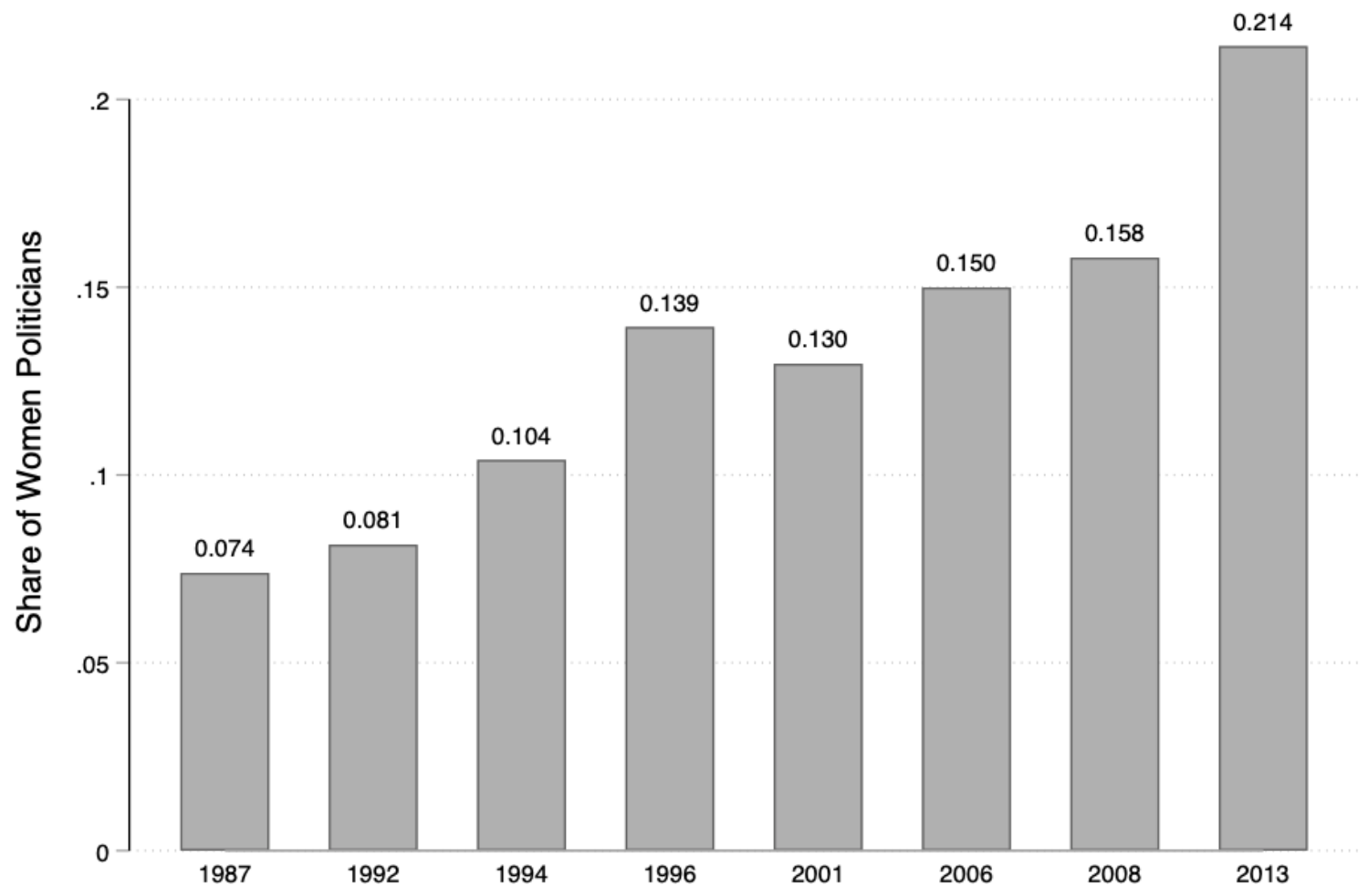

Figure 1. Share of women politicians, over time, aggregated across all levels of government 


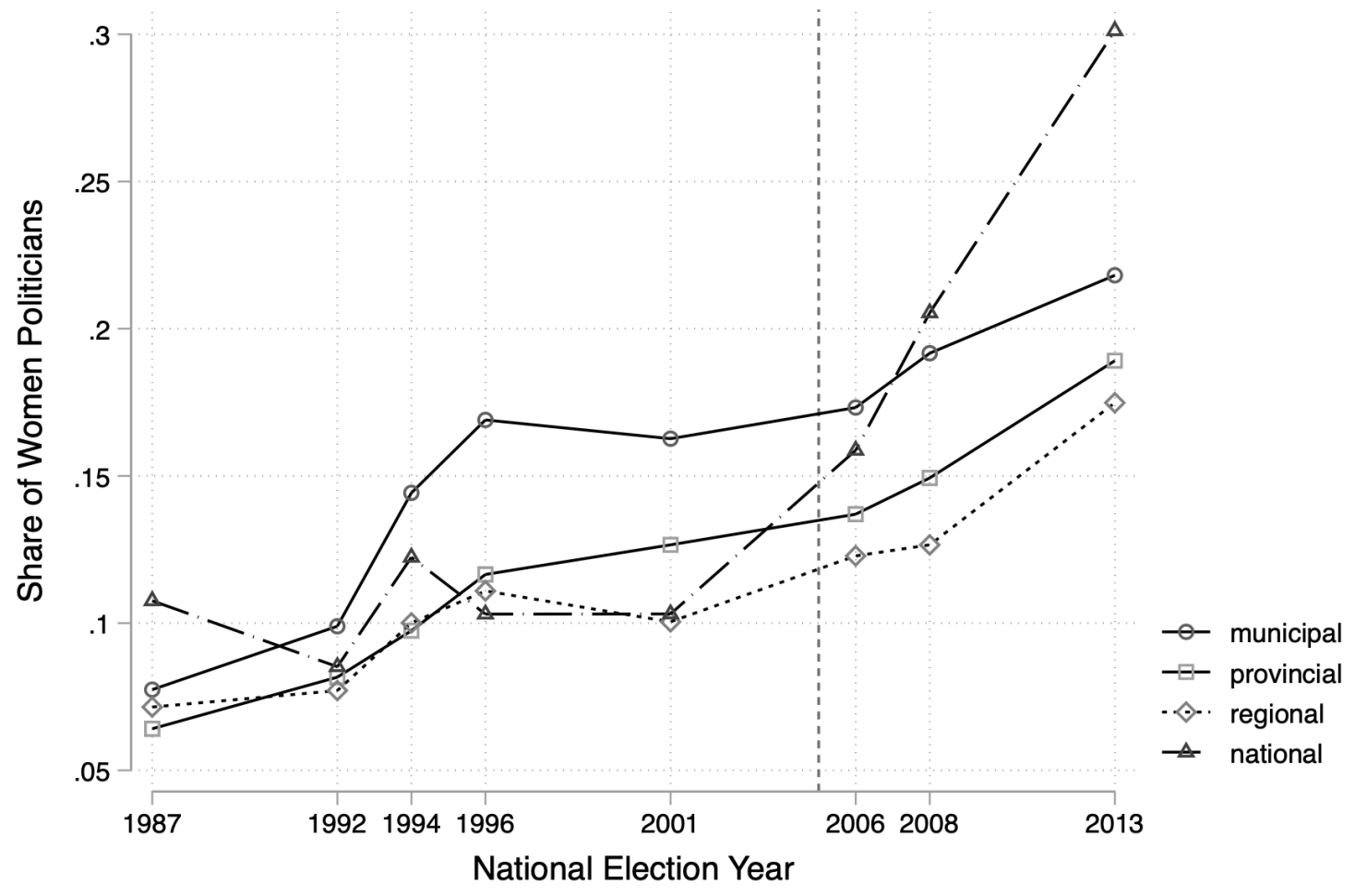

Figure 2. Share of women politicians at each level of government, full sample

Moving to national politicians, we first collect aggregate data on the candidates ${ }^{4}$ who put themselves forward for the national elections in the period 1987-2013 (Castiglioni, 2020). For the 2013 national election only, we also have detailed information at the individual level on candidates (age, gender, education, district of election and of birth, profession, party affiliation), drawn from Galasso and Nannicini (2015).

We then collect data on elected politicians at the national level, i.e. members of the Italian Parliament from 1987 to 2013. For the national elections of 1987, 1992, 1994, 1996, 2001 and 2006 data come from Gagliarducci et al. (2011) and include detailed demographic characteristics (age, gender, place of residence, education), self-declared

\footnotetext{
${ }^{4}$ Data on candidates are available only for national elections, as there is no systematic collection of data on candidates at subnational levels.
} 
previous job, parliamentary appointments (president, vice-president, secretary of the parliament or of a legislative committee), party affiliation and experience (member of the party directive board at the local, regional or national level), local government experience (mayor, councillor, regional president etc.) and system of election. Similar data containing individual characteristics on elected politicians are provided by Armando Miano for the 2008 election and from Galasso and Nannicini (2015) for the 2013 election, which also contain information on political candidates.

The same datasets also provide the variables which we use as controls in the main analysis: year (a linear time trend), region of election, and the regional magnitude for the region where the politician is elected. ${ }^{5}$ Summary statistics about the individual characteristics of these politicians are provided in Table 1 (all levels of government), Table 2 (national politicians, 1994-2001), and Table 3 (national politicians, 2013).

We have three different measures of education in the datasets that we rely upon for our analyses. One captures the years of schooling $(5,8,13,17$ or 20 years - for the national politician data (Gagliarducci et al., 2011)), one captures in a categorical manner education levels from no schooling to degree level (categories 0-9 from no education to a university degree - for the 2013 politicians and candidates data (Galasso and Nannicini, 2015)), and one captures in a (different) categorical manner education from no schooling to degree level (categories 1-5 - for the subnational data, Ministry of Internal Affairs). These three measures are all standardised into a single comparable, categorical variable,

\footnotetext{
${ }^{5}$ The number of seats available per region is calculated by summing the electoral districts within a given region. We do this as districting changed across electoral systems over time, but the geographical regions remained the same so the seats available within their borders are comparable.
} 
such that 1: primary education, 2: middle school education, 3: high school education, 4: degree-level or equivalent education, 5: PhD or equivalent education.

Table 1. Summary Statistics

\begin{tabular}{lcccccc}
\hline \hline \multicolumn{7}{c}{ Panel A: All Levels } \\
\hline & male & treated & post & year & regions & reg. magn. \\
\hline mean & 0.852 & 0.007 & 0.319 & 1999 & 1.745 & 48.281 \\
p50 & 1.000 & 0.000 & 0.000 & 2000 & 1.000 & 48.000 \\
$\min$ & 0.000 & 0.000 & 0.000 & 1987 & 1.000 & 1.000 \\
$\max$ & 1.000 & 1.000 & 1.000 & 2013 & 4.000 & 101.000 \\
\hline$N$ & $4,254,905$ & \multicolumn{1}{c}{} \\
\hline \hline
\end{tabular}

\begin{tabular}{lcccccc}
\hline \hline \multicolumn{7}{c}{ Panel B: Pre-Treatment, Control } \\
\hline & male & treated & post & year & regions & reg. magn. \\
\hline mean & 0.871 & 0.000 & 0.000 & 1995 & 1.737 & 48.185 \\
p50 & 1.000 & 0.000 & 0.000 & 1995 & 1.000 & 48.000 \\
$\min$ & 0.000 & 0.000 & 0.000 & 1987 & 1.000 & 1.000 \\
$\max$ & 1.000 & 0.000 & 0.000 & 2004 & 3.000 & 99.000 \\
\hline$N$ & $2,554,870$ & & & & & \\
\hline
\end{tabular}

\begin{tabular}{lcccccc}
\hline \hline \multicolumn{7}{c}{ Panel C: Pre-Treatment, Treated } \\
\hline & male & treated & post & year & regions & reg. magn. \\
\hline mean & 0.895 & 1.000 & 0.000 & 1995 & 1.897 & 49.973 \\
p50 & 1.000 & 1.000 & 0.000 & 1995 & 2.000 & 49.000 \\
$\min$ & 0.000 & 1.000 & 0.000 & 1987 & 1.000 & 1.000 \\
$\max$ & 1.000 & 1.000 & 0.000 & 2004 & 3.000 & 99.000 \\
\hline$N$ & $17,361.00$ & & \\
\hline \hline
\end{tabular}
i.e. overseas district).

Our final dataset delivers a complete picture of women's political representation at all levels of government for the same country and its evolution over the considered period. As aforementioned, such a comprehensive picture is rare in existing studies. A table summarising our data sources is provided in the Appendix (Section 2, Table A1). ${ }^{6}$

\footnotetext{
${ }^{6}$ Replication materials and code can be found at Profeta and Woodhouse (2021).
} 
Table 2. Summary Statistics: National Only, 1994-2001

\begin{tabular}{lccccc}
\hline \hline & & & & \\
& male & age & edu. & subnat. exp. & incumbent \\
\hline mean & 0.914 & 48.248 & 15.976 & 2.681 & 0.198 \\
p50 & 1.000 & 48.000 & 17.000 & 0.000 & 0.000 \\
$\min$ & 0.000 & 27.000 & 5.000 & 0.000 & 0.000 \\
$\max$ & 1.000 & 84.000 & 20.000 & 19.000 & 1.000 \\
\hline$N$ & 1,305 \\
\hline Note: male $=1$, female $=0$, age in years, education level \\
(in years of schooling: $5,8,13,17$ or 20 . These values are \\
later standardised as described in Section 4, p. 12), years \\
of sub-national political experience, and incumbent status \\
(incumbent = 1, non-incumbent $=0$ ).
\end{tabular}

Table 3. Summary Statistics: National Only, 2013

\begin{tabular}{lccccc}
\hline \hline & & & & & \\
& male & age & edu. & subnat. exp. & incumbent \\
\hline mean & 0.697 & 48.946 & 5.714 & 1.644 & 0.346 \\
p50 & 1.000 & 49.000 & 6.000 & 0.000 & 0.000 \\
$\min$ & 0.000 & 25.000 & 0.000 & 0.000 & 0.000 \\
$\max$ & 1.000 & 89.000 & 9.000 & 21.000 & 1.000 \\
\hline$N$ & 926 \\
\hline Note: as above, except: education which is categorised as 0, \\
3/9 from no schooling to degree level. These values are later \\
standardised to match with the other datasets, as described \\
in Section 4, p. 12.
\end{tabular}




\section{Empirical Strategy and Main Results}

We use our dataset to answer the following questions:

1. Are more women politicians elected under a proportional electoral system than under a majoritarian system?

2. Does the qualification of elected politicians change with the electoral reform (from majoritarian to proportional)?

\subsection{The Reform and the Election of Women}

We take a DiD approach in order to identify within-country electoral system effects on the political career outcomes of women. The treated group is made up of the national level politicians who were exposed to the 2005 change in electoral rule from a mixed, largely majoritarian system to a proportional system. ${ }^{7}$ The control group is made up of subnational politicians, who were not exposed to the change in electoral rule.

Only $0.7 \%$ of politicians in our sample move from subnational politics to national politics over the course of their careers, which suggests that our treated group is generally not contaminated by the control group. Moreover, subnational and national elections occur at different times and preparing a national-level political campaign requires time, making it difficult for politicians to easily or quickly switch from control to treatment group. In order to address concerns that our effect may be driven by a decline in the

\footnotetext{
${ }^{7}$ Life senators are excluded from all analyses as they are unelected figures. For the majoritarian elections, we only consider politicians elected in the majoritarian tier. In the Appendix, Section 4, we also exploit the two-tiered feature of the Mattarellum reform to compare elected politicians in the majoritarian and proportional tiers of the same level of national government.
} 


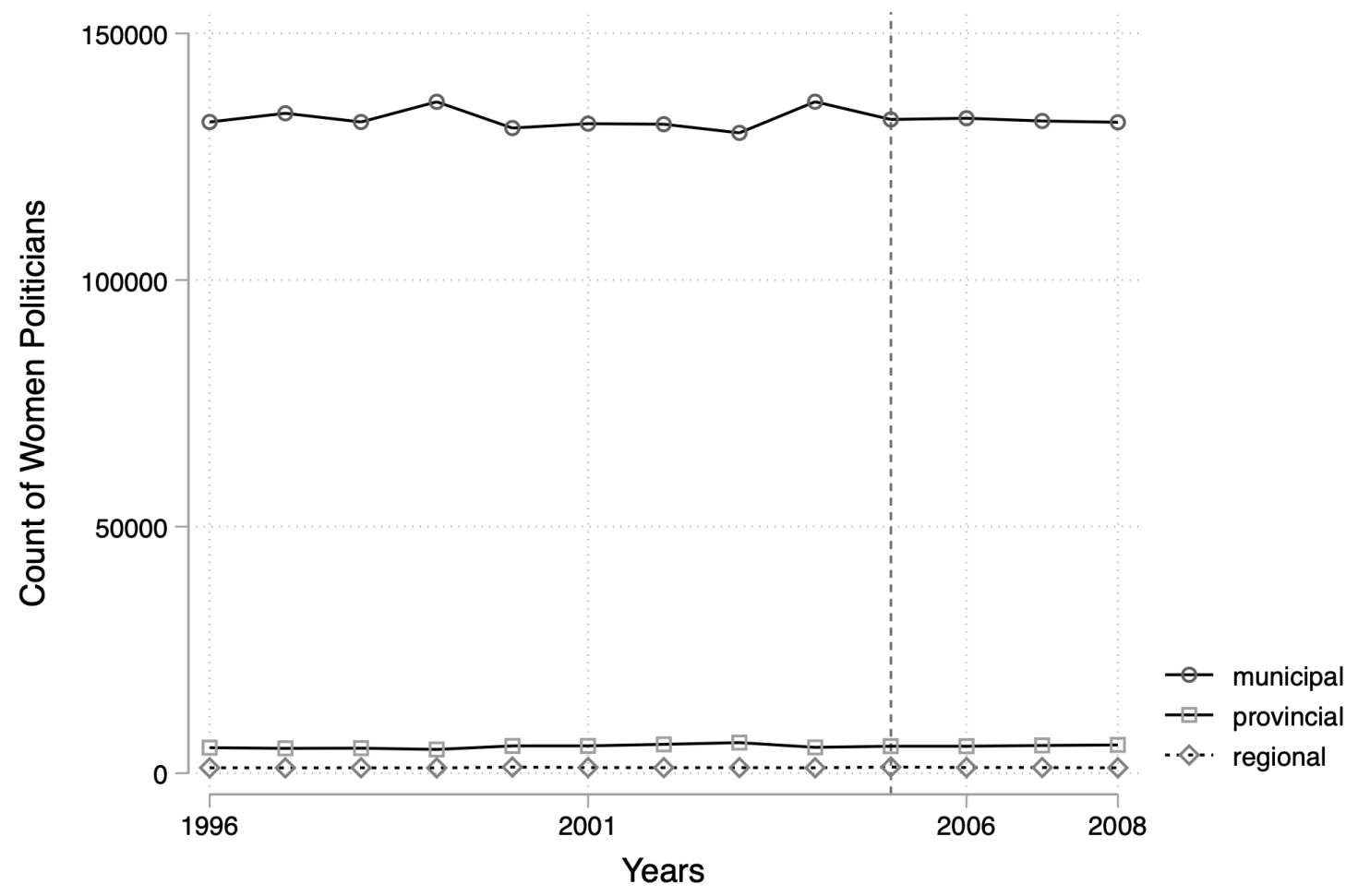

Figure 3. Count of women politicians at subnational levels of government

number of women politicians at the subnational level in the years running up to and just after the reform, in Figure 3 we focus on the two national elections either side of the 2005 reform and show that the number of women politicians at the subnational levels of government does not change in these years. If the reform attracts more, new women to national politics (as Figures A1 and A2 in the Appendix would indicate), then this does not seem to come at the cost of subnational women's representation.

For our main analyses we exclude the years 2012 and 2013 as the effect of the 2005 reform could be contaminated by a subnational reform implemented at the very end of 2012 (Legge n.215, see the dotted arrow on Timeline A2 in the Appendix). ${ }^{8}$ We also exclude the years prior to the national election of 1994, as the national electoral system

\footnotetext{
${ }^{8}$ See the Appendix, Section 1 for more information.
} 
was reformed in 1993 and these years could contaminate our results (Appendix, Sections 1.2 and 7). This means that, for our main analyses, the pre-reform period refers to the years 1994-2005 (national elections: 1994, 1996, 2001) ${ }^{9}$ and the post-reform period refers to the years 2006-2011 (national elections: 2006, 2008).

In order to justify inference from the DiD model, in addition to classical linear regression model assumptions, parallel trends have to be verified, i.e. the subnational (control) and national (treated) groups must have been moving in parallel to one another in terms of women political representation ahead of the 2005 reform which, we argue, exogenously affected the number of women being elected to national office, but not to subnational offices. If these parallel trends hold, then the DiD estimator can be interpreted as the treatment effect on the treated. Thus, the difference in pre- and post-treatment differences equates to the effect of the 2005 reform on national level women's representation.

Parallel trends are shown in Figures 4 and $5 .{ }^{10}$ We note that each point on the graph represents a year and the $\mathrm{x}$ axis indicates national election years. There are idiosyncratic changes in the numbers of deputies at the national level by year (but within the same mandate) as deputies occasionally stand down from their positions or pass away. This is why we see slight changes in the number of deputies even in years when there is not a new national election. The vertical line represents the reform year (2005) and the y axis

\footnotetext{
${ }^{9}$ Our results remain unchanged if we exclude the election year 1994 . One might worry that 1994 could skew the results given that in this election year legislation was in place to ensure that neither sex could be represented by more than $75 \%$ of all candidates, alongside a zipper system whereby male and women candidates would appear alternately on party lists. These laws were declared unconstitutional and abolished in 1995 .

${ }^{10}$ We check for discontinuities in other trends around the date of the reform in the Appendix, Section 3.
} 
indicates the share of elected women politicians.

In the equations that follow, $l$ refers to the level of government that the individual politician $(i)$ has been elected to (national, regional, provincial or municipal) and $t$ refers to the time period of the election. We present both aggregate estimates where all variables are measured at the average level for the level of government and time period in question and individual level estimates.

We first estimate the following equations on aggregate data:

$$
Y_{l t}=\alpha+\gamma T R E A T_{l}+\lambda P O S T_{t}+\delta_{D i D}\left(T R E A T_{l} \times P O S T_{t}\right)+e_{l t}
$$

$$
Y_{l t}=\alpha+\gamma T R E A T_{l}+\lambda P O S T_{t}+\delta_{D i D}\left(T R E A T_{l} \times P O S T_{t}\right)+\beta_{t} T I M E T R E N D+e_{l t}
$$

$Y_{l t}=\alpha+\gamma T R E A T_{l}+\lambda P O S T_{t}+\delta_{D i D}\left(T R E A T_{l} \times P O S T_{t}\right)+\beta_{t} T I M E T R E N D+\boldsymbol{X}_{l t}^{\prime} \beta+e_{l t}$

Where $Y_{l t}$ is the share of women in political level $l$ and year $t, T R E A T_{l}$ is a dummy variable equal to 1 if we consider women elected at the national level and to 0 for subnational levels, $P O S T_{t}$ is a dummy variable equal to 1 if the politician has been elected after 2005 and 0 for years before, and the interaction term $T R E A T_{l} \times P O S T_{t}$ indicates national observations for post-reform years. $\delta_{D i D}$ is the DiD estimate that 


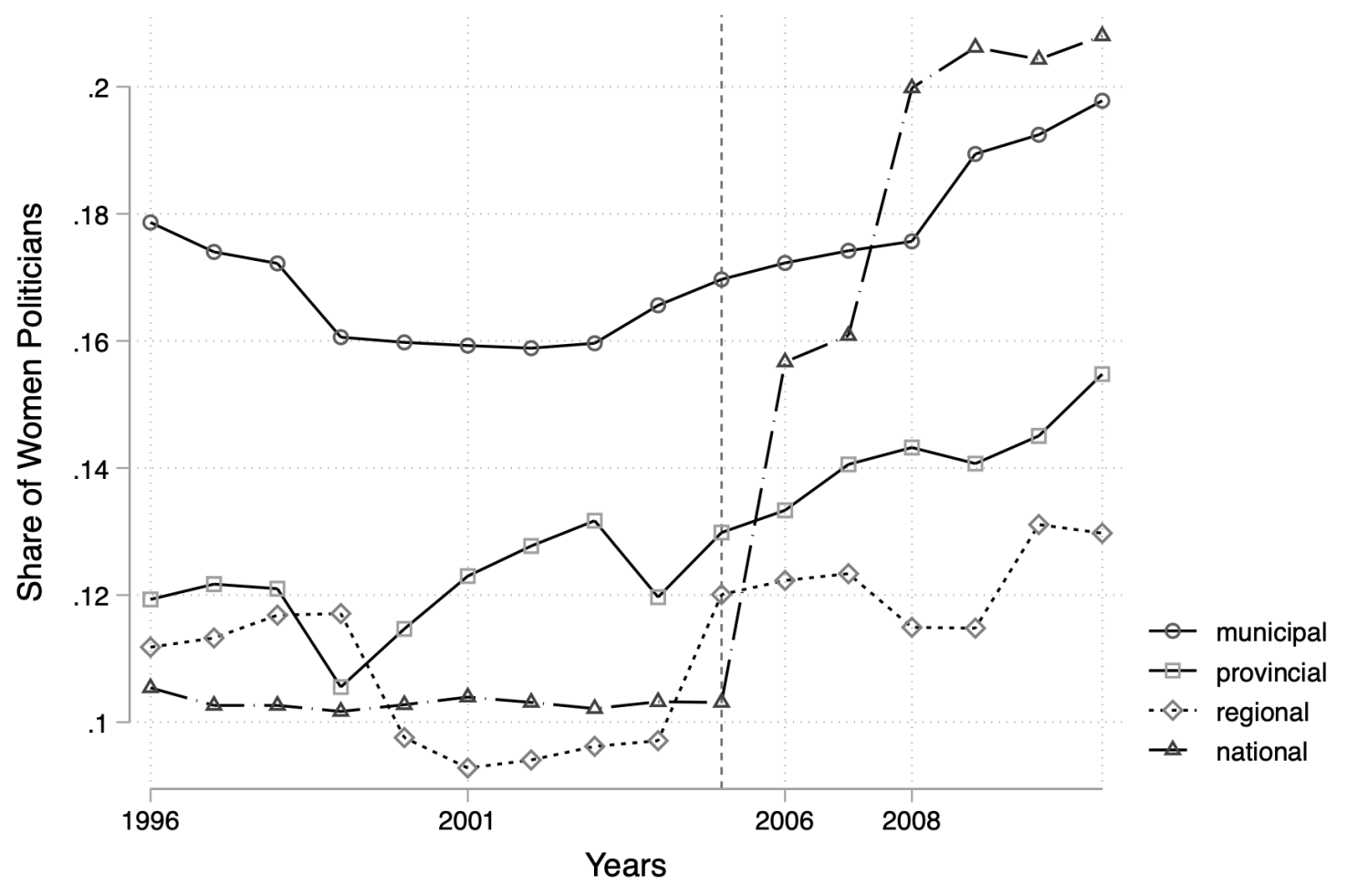

Figure 4. Parallel trends, all levels of government



Figure 5. Parallel trends, treated (national) and control (subnational) groups 
captures the effect of the 2005 reform on the share of women politicians in national office. $\beta_{t}$ TIMETREND is a linear time trend. $\boldsymbol{X}_{l t}^{\prime}$ is a vector of controls, comprised of a categorical variable capturing the macro regions of Italy (North, Centre, South and Overseas $^{11}$ ) and a variable capturing regional magnitude (district magnitude pooled to the regional level ${ }^{12}$ ). Descriptive statistics for these variables are presented in Table 1.

Thus, $\alpha$ captures the effect for the non-treated group (subnational politicians) prior to the reform, $\alpha+\gamma$ captures the effect for the treated group (national politicians) prior to the reform, $\alpha+\lambda$ captures the effect for the non-treated group post-reform and $\alpha+\gamma+\lambda+\delta$ captures the effect for the treated group post-reform.

We also estimate equivalent equations using individual level information:

$$
Y_{i l t}=\alpha+\gamma T R E A T_{i l}+\lambda P O S T_{i t}+\delta_{D i D}\left(T R E A T_{i l} \times P O S T_{i t}\right)+e_{i l t}
$$

$Y_{i l t}=\alpha+\gamma T R E A T_{i l}+\lambda P O S T_{i t}+\delta_{D i D}\left(T R E A T_{i l} \times P O S T_{i t}\right)+\beta_{i t} T I M E T R E N D+e_{i l t}$

\footnotetext{
${ }^{11}$ Our data also include Italy's overseas districts: Europa, America Meridionale, America Settentrionale e Centrale, and Africa, Asia, Oceania ed Antartide.

${ }^{12}$ District magnitudes are discussed in the Appendix, Section 1.2.
} 
$Y_{i l t}=\alpha+\gamma T R E A T_{i l}+\lambda P O S T_{i t}+\delta_{D i D}\left(T R E A T_{i l} \times P O S T_{i t}\right)+\beta_{i t} T I M E T R E N D+\boldsymbol{X}_{i}^{\prime} \beta+e_{i l t}$

Where $Y_{i l t}$ is a dummy variable equal to 1 if the politician $i$ elected at level $l$ and year $t$ is a woman and 0 if he is a man. The other variables are the same as in Equations 1, 2 and 3 , but measured at the individual level for politician $i$.

Results are presented in Table $4 .{ }^{13}$ Using the fullest specification (Column 6, Table 4), the marginal effect on the likelihood of seeing a woman elected to national office moves from $12 \%$ prior to the reform to $17 \%$ following the reform, an increase of 5 percentage points. The message to be taken from Table 4 is that the 2005 reform changing the electoral rule from a majoritarian to a proportional system has a statistically significant, positive impact on women elected to national office. ${ }^{14}$ The share of women elected to subnational offices was following a positive trend ahead of the reform (Row 1) and the share of women elected to subnational offices prior to the reform was significantly higher than the share of women elected to national office (Row 2). The change in the electoral rule modified the national representation of women significantly (Row 3), compensating for the pre-existing higher levels of women's representation at the subnational levels $($ Treatment + Post $*$ Treatment $) .{ }^{15}$ Robustness analyses are presented in the Appendix,

\footnotetext{
${ }^{13}$ The numbers of the equations match the column numbers in Table 4.

${ }^{14}$ We exclude three regions (Valle d'Aosta, Molise, and Trentino-Alto Adige) from our analyses because they elected their deputies with a different (majoritarian) system in the post-reform period.

${ }^{15}$ For example, in the case of Column 1 the mean difference in the share of women being elected to national office was $-0.052+0.051=0.001$, as compared to the prior difference of -0.052 .
} 
Section 7. Amongst the robustness tests (Table A5), we also include alternative cut-off dates for the estimation sample.

Table 4. Share of Women Elected and Female Election Probability

\begin{tabular}{lcccccc}
\hline VARIABLES & $(1)$ & $(2)$ & $(3)$ & $(4)$ & $(5)$ & $(6)$ \\
\hline \multirow{2}{*}{ post } & & & & & & \\
& $0.018^{* * *}$ & 0.002 & 0.000 & $0.018^{* * *}$ & $0.003^{* * *}$ & $0.003^{* * *}$ \\
treated & $(0.006)$ & $(0.011)$ & $(0.007)$ & $(0.001)$ & $(0.001)$ & $(0.001)$ \\
& $-0.052^{* * *}$ & $-0.052^{* * *}$ & $-0.059^{* * *}$ & $-0.052^{* * *}$ & $-0.052^{* * *}$ & $-0.046^{* * *}$ \\
post*treated & $(0.006)$ & $(0.006)$ & $(0.005)$ & $(0.008)$ & $(0.008)$ & $(0.008)$ \\
& $0.051^{* * *}$ & $0.051^{* * *}$ & $0.047^{* * *}$ & $0.052^{* * *}$ & $0.052^{* * *}$ & $0.051^{* * *}$ \\
& $(0.016)$ & $(0.015)$ & $(0.009)$ & $(0.011)$ & $(0.011)$ & $(0.011)$ \\
Observations & 36 & 36 & 108 & $2,364,875$ & $2,364,875$ & $2,364,258$ \\
R-squared & 0.709 & 0.729 & 0.787 & 0.001 & 0.001 & 0.009 \\
Time Trend & NO & YES & YES & NO & YES & YES \\
Controls & NO & NO & YES & NO & NO & YES \\
\hline
\end{tabular}

Note: dependent variable, Columns 1-3: share of female politicians, aggregate data. Dependent variable, Columns 4-6: politician (binary, female $=1$, male $=0$ ), individual data. Standard errors are clustered at the national-subnational levels (Columns 1-3) and at the individual level (Columns 4-6) and are reported in parenthesis. The mean value for the outcome variables and descriptive statistics for control variables are presented in Table 1. Variables are described in Section 4 of the main text. In Columns 1 and 4, we estimate Equations 1 and 4, in Columns 2 and 5 we add a time control (as seen in Equations 2 and 5), and in Columns 3 and 6, we bring in the additional controls (as seen in Equations 3 and 6). The change in number of observations in Model 3 is due to the introduction of the macro regions control, which means that the data are re-aggregated across the macro-regions instead of only across the national-subnational split. $* * * \mathrm{p}<0.01,{ }^{* *} \mathrm{p}<0.05,{ }^{*} \mathrm{p}<0.1$

In Table 5, we present equivalent results to equation 2 (Table 4, Column 6) broken down by party affiliation to show that the effect of the reform is not driven by a specific party. This responds to concerns that a single party (for example, Berlusconi's Forza Italia) might be driving the effect of the electoral reform on national women's representation. 
Table 5. Share of Women Elected and Female Election Probability, by Party

\begin{tabular}{|c|c|c|c|c|c|}
\hline VARIABLES & $\begin{array}{l}(1) \\
\text { Left }\end{array}$ & $\begin{array}{c}(2) \\
\text { Centre-Left }\end{array}$ & $\begin{array}{c}(3) \\
\text { Centre }\end{array}$ & $\begin{array}{c}(4) \\
\text { Centre-Right }\end{array}$ & $\begin{array}{c}(5) \\
\text { Right }\end{array}$ \\
\hline post & $\begin{array}{c}0.001 \\
(0.002)\end{array}$ & $\begin{array}{c}-0.019 * * * \\
(0.004)\end{array}$ & $\begin{array}{c}0.016^{* * *} \\
(0.003)\end{array}$ & $\begin{array}{l}0.004^{*} \\
(0.002)\end{array}$ & $\begin{array}{c}0.016^{* * *} \\
(0.004)\end{array}$ \\
\hline treated & $\begin{array}{l}-0.029 \\
(0.019)\end{array}$ & $\begin{array}{l}-0.017 \\
(0.040)\end{array}$ & $\begin{array}{c}-0.072^{* *} \\
(0.035)\end{array}$ & $\begin{array}{c}-0.055^{* * *} \\
(0.012)\end{array}$ & $\begin{array}{c}-0.076^{* * *} \\
(0.016)\end{array}$ \\
\hline post*treated & $\begin{array}{c}0.054^{* *} \\
(0.026)\end{array}$ & $\begin{array}{l}0.079^{*} \\
(0.042)\end{array}$ & $\begin{array}{c}0.039 \\
(0.050)\end{array}$ & $\begin{array}{l}0.041^{* *} \\
(0.017)\end{array}$ & $\begin{array}{c}0.078^{* * *} \\
(0.024)\end{array}$ \\
\hline $\begin{array}{l}\text { Observations } \\
\text { R-squared }\end{array}$ & $\begin{array}{c}608,457 \\
0.011\end{array}$ & $\begin{array}{c}94,746 \\
0.019\end{array}$ & $\begin{array}{c}230,088 \\
0.009\end{array}$ & $\begin{array}{c}285,405 \\
0.004\end{array}$ & $\begin{array}{c}132,309 \\
0.008\end{array}$ \\
\hline $\begin{array}{l}\text { Note: depend } \\
\text { Baseline regre } \\
\text { mean value } \mathrm{f} \\
\text { variables are } \\
\text { each of the ca } \\
\text { variously nan } \\
\text { regions/provir } \\
\text { exemplify: Le } \\
\text { Italiano and } \\
\text { Democratico } \\
\text { Partito Reput } \\
\text { Democrazia C } \\
\text { includes Alleo } \\
* * \mathrm{p}<0.05, *\end{array}$ & $\begin{array}{l}\text { nt variab } \\
\text { ssions wit } \\
\mathrm{r} \text { the out } \\
\text { resented } \\
\text { egories he } \\
\text { ed civic li } \\
\text { ces/munic } \\
\text { includes } \\
\text { emocrati } \\
\text { nd La Mc } \\
\text { blicano It } \\
\text { istiana, F } \\
\text { iza Nazio } \\
<0.1\end{array}$ & $\begin{array}{l}\text { (binary, pc } \\
\text { controls. Eq } \\
\text { me variable } \\
\text { Table } 1 . \text { We } \\
\text { as there are } \\
\text { s and chang } \\
\text { alities), but } \\
\text { artito Democ } \\
\text { di Sinistra; } \\
\text { gherita; Cen } \\
\text { ano and Un } \\
\text { za Italia and } \\
\text { le, Fiamma }\end{array}$ & $\begin{array}{l}\text { itician: fe } \\
\text { livalent to } \\
\text { and descr } \\
\text { cannot lis } \\
\text { lundreds v } \\
\text { g party n } \\
\text { ach data is } \\
\text { atico della } \\
\text { Centre-Lef } \\
\text { ce include } \\
\text { one di Cer } \\
\text { Cristiani } L\end{array}$ & $\begin{array}{l}\text { nale }=1 \text {, mal } \\
\text { Column } 6 \text { of } \\
\text { ptive statistic } \\
\text { all the partie } \\
\text { ithin each cat } \\
\text { ames over tim } \\
\text { available upor } \\
\text { Sinistra, Parti } \\
\text { includes } L ' L \\
\text { Partito Popo } \\
\text { tro; Centre-R } \\
\text { emocratici Un }\end{array}$ & $\begin{array}{l}=0 \text { ). OLS. } \\
\text { ble } 4 \text {. The } \\
\text { for control } \\
\text { ncluded in } \\
\text { bry (due to } \\
\text { and across } \\
\text { equest. To } \\
\text { Comunista } \\
\text { o, Partito } \\
\text { re Italiano, } \\
\text { t includes } \\
\text { and Right }\end{array}$ \\
\hline
\end{tabular}

\subsection{The Reform and the Qualification of Politicians}

In this section, we analyse the effect of electoral rules on the qualification of elected politicians. We use the term qualification rather than quality to reflect the difficulty in capturing the ability of an individual to perform political tasks successfully. ${ }^{16}$ Since measuring political qualification is a notoriously difficult task and one that suffers from

\footnotetext{
${ }^{16}$ Through our measures of political experience and education we can claim to capture significant dimensions of an individual's likelihood of being qualified and successful as a politician (e.g. competence and honesty (Besley and Reynal-Querol, 2011)), but not to have a comprehensive measure of their overall quality.
} 
gendered biases (Murray, 2015), we rely on two alternative measures, using education and previous experience, in line with the literature (Jacobson, 1989; Shugart et al., 2005; Galasso and Nannicini, 2011). We propose that higher education and more subnational political experience proxy higher levels of qualification. Formal skills, and perhaps soft competence, acquired through education are important ingredients for politicians' qualification. The value of education for the qualification of politicians is also recognised by voters and parties, as educated candidates tend to receive more votes and more campaign funds from political parties (Cavalcanti et al., 2018). We recognise that there is debate surrounding the extent to which a college degree is a signal of a good politician (Carnes and Lupu, 2016) and that political preferences are broadly stable and more likely to be informed by one's socio-economic upbringing than by a higher educational experience (O’Grady, 2019). ${ }^{17}$ To support our use of education as a measure of qualification, we also perform our analysis by party (as will be discussed later in this Section). We also create a measure of the share of politicians who are parachuted to the national level with no subnational experience whatsoever, as a proxy of low qualification.

The existing literature has found that the women elected to office are as or more qualified than equivalent men politicians (see Section 1). We confirm that this is also the case in Italy. When addressing our second research question, it is unfortunately not possible to follow the same methodology as for the first. We cannot undertake a DiD analysis for education, as the parallel trends assumption does not hold for the education

\footnotetext{
${ }^{17}$ We note that Italy has a public university system, means-tested (and low) university fees, and most Italian students live at home whilst they pursue further education. This means that a tertiary education is more accessible than in other contexts.
} 
levels of national and subnational politicians in our sample. We thus have to rely on a simpler comparison of our measures of qualification by gender before and after the reform.

We consider the average measure and its distribution.

Table 6. Qualification of National Politicians, Pre- and Post-Reform

\begin{tabular}{||c|c|c|c||}
\hline \multicolumn{5}{|c|}{ Panel A: Pre/Post Comparisons } \\
\hline \hline Measure of Qualification & Pre vs. Post: Overall & Pre vs. Post: Men & Pre vs. Post: Women \\
\hline Education Level & $-0.102^{* * *}$ & $-0.103^{* * *}$ & $-0.085^{* * *}$ \\
\hline Years of Sub-Nat. Exp. & $+1.389^{* * *}$ & $+1.489^{* * *}$ & $+1.302^{* * *}$ \\
\hline Parachuters & $-0.059^{* * *}$ & $-0.077^{* * *}$ & 0.028 \\
\hline
\end{tabular}

\begin{tabular}{|c|c|c|c|c|c|c|}
\hline \multicolumn{7}{|c|}{ Panel B: Absolute Measures } \\
\hline Measure of Qualification & Pre vs. Pc & st: Overall & Pre vs. 1 & ost: Men & Pre vs. Pc & t: Women \\
\hline Education Level & 3.813 & 3.711 & 3.818 & 3.716 & 3.774 & 3.689 \\
\hline Years of Sub-Nat. Exp. & 3.120 & 4.509 & 3.232 & 4.722 & 2.196 & 3.497 \\
\hline Parachuters & 0.251 & 0.192 & 0.252 & 0.175 & 0.243 & 0.271 \\
\hline
\end{tabular}

Note: Education level: ranges from 1 (primary education), to 5 ( $\mathrm{PhD}$ or equivalent). Subnational experience: measured in years. A parachuter politician (binary variable) is one who arrives at the national level with 0 years of subnational experience; figures shown represent the share of parachuters over the total of national politicians. ${ }^{* * *} \mathrm{p}<0.01,{ }^{* *} \mathrm{p}<0.05,{ }^{*} \mathrm{p}<0.1$

As can be seen in Panel A of Table 6, two out of three qualification measures (subnational experience and the share of parachuters) improve with the reform. The education level of elected politicians decreases with the reform, but by a small amount (around one tenth of an education level, which amounts to approximately one seventh of a standard deviation). There are slightly more women parachuters following the reform, but this is not statistically significant. It is difficult to argue, then, that following the 2005 reform the qualification of politicians decreases. If anything, overall qualification levels seem to increase, with similar levels of education, more subnational experience for both men and women, and fewer men parachuters.

Our data also reveal that at all subnational levels of government for all the years 
available in our sample, women politicians are more educated than their male counterparts and the differences are statistically significant at the 0.01 level (see Figure 6). Interestingly, there seems to be a selection effect at the national level, whereby this difference disappears.

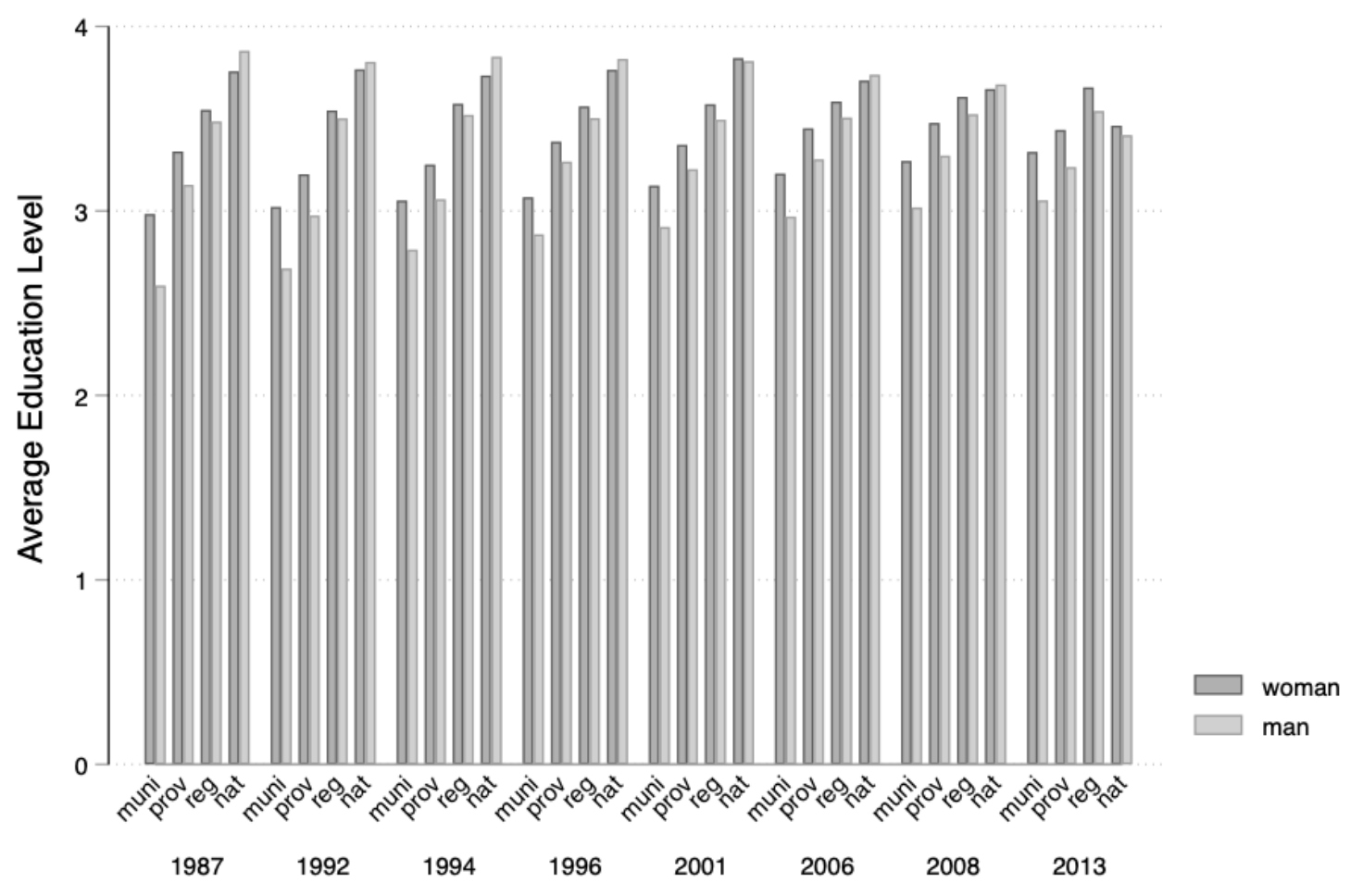

Figure 6. Average education level by gender, all levels, over national election years 
In order to analyse this selection question at the national level more closely, we use detailed candidate data, which include information on the individual level of education, which are available only for the 2013 election. Figure 7 shows the kernel distribution of the education level of all male and women candidates (Panel A) and elected men, elected women, non-elected men and non-elected women (Panel B). Women candidates are more educated than their male counterparts. Indeed, non-elected women are the most educated of all the categories of politicians i.e. these unelected women are more educated than elected men politicians. Whereas there is no difference in the qualification of elected men and women or between male candidates and elected politicians, the best women candidates are left behind. Kolmogorov-Smirnov tests for equality of distribution functions for each of these education level distributions confirm that the differences are statistically significant. This evidence suggests that, while overall the election of women does not come at the expense of the qualification level of representatives, the proportional system is not able to select the best women - this is in line with recent contributions regarding proportional electoral rules undermining the selection of good politicians (Becher and González, 2019). The qualification of politicians would benefit from a further increase in elected women. 
PANEL A: ALL (CANDIDATES AND ELECTED)

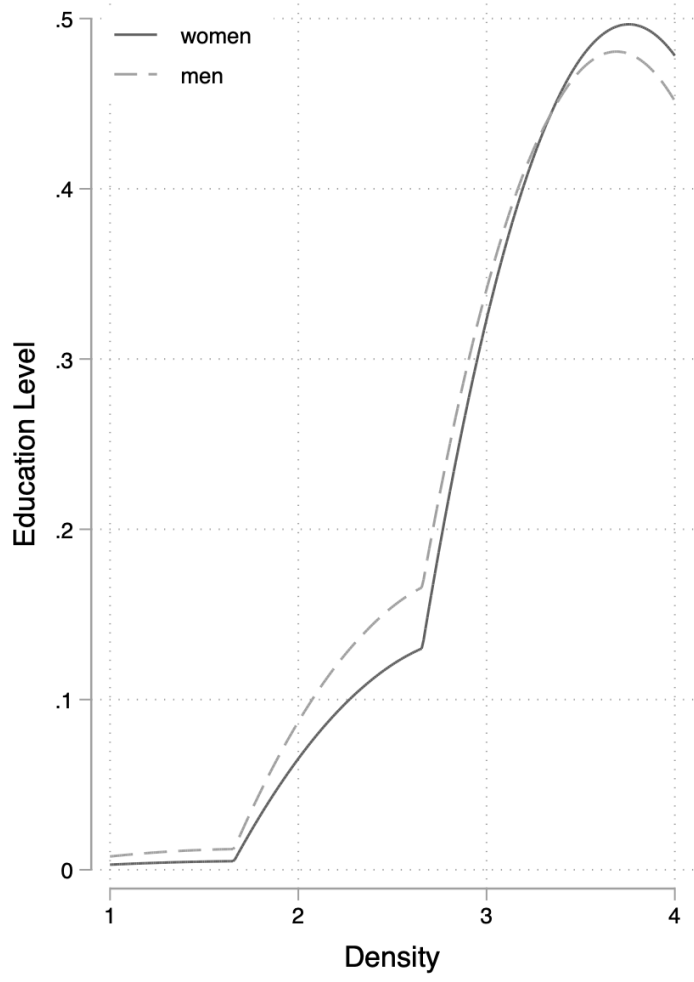

PANEL B: ELECTED vs. CANDIDATE POLITICIANS

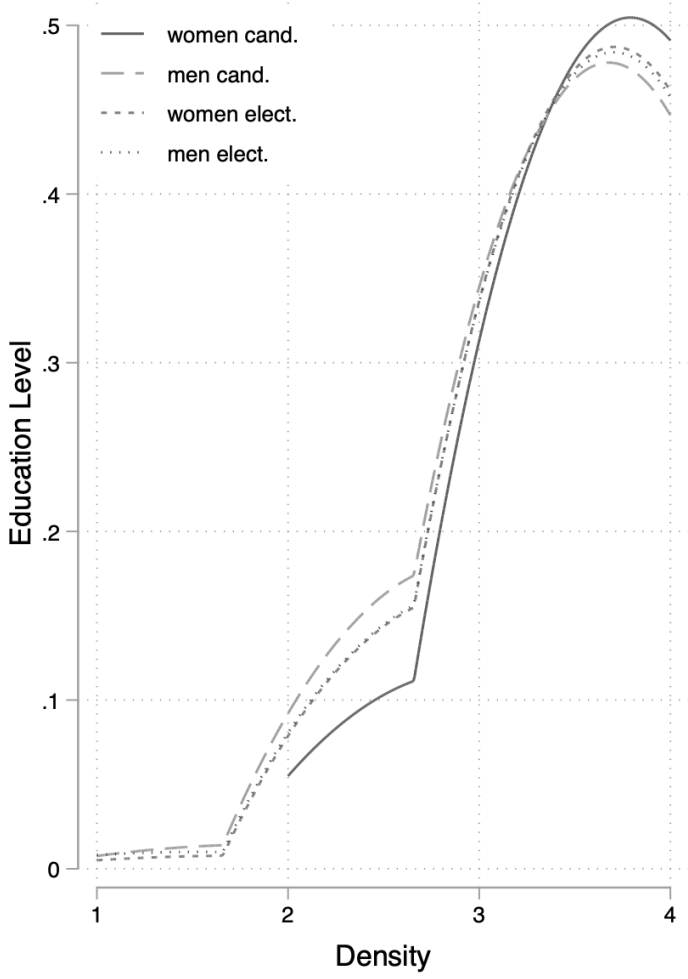

Figure 7. 2013 election, non-elected vs. elected politicians, kernel density estimates*

*A reminder that our standardised measure of education is such that, 1: primary education, 2 : middle school education, 3: high school education, 4: degree-level or equivalent education, 5:

$\mathrm{PhD}$ or equivalent education (as described in Section 4). 
To clarify the effects on qualification summarised by Table 6 , in Table 7 we focus on education level as a measure of qualification and divide politicians in two groups, low and high education. ${ }^{18}$ In majoritarian elections, $12 \%$ of elected politicians are women ( $88 \%$ men), while these percentages become $19 \%(81 \%)$ in proportional elections, respectively. Prior to the reform, $76 \%$ of the elected women are high education and $24 \%$ are low education, while for men the respective percentages are $74 \%$ and $26 \%$. Following the reform, so under proportional representation rules, $73 \%$ of elected women are high education and $27 \%$ are low education, whereas for men the respective percentages are $72 \%$ and $28 \%$. What we see, then, is that prior to the reform at the national level women politicians had a slightly lower education level than men (see Figure 6), whereas following the reform this difference disappears (note that at the subnational levels, women politicians' education level remains higher than men politicians' across the board, see Figure 6). ${ }^{19}$

When we look at the 2013 election, high education women represent $76 \%$ amongst the non-elected women, but they represent only $69 \%$ amongst elected women (Table 7 , Panels $\mathrm{C}$ and $\mathrm{D})$. The best women in the pool of candidates are, therefore, not elected: the number of high education women left in the unelected pool is greater than that in

\footnotetext{
${ }^{18}$ High education politicians are those with educational qualifications equivalent to a Bachelor's degree or above and low education politicians are those with educational qualifications equivalent to anything less than a Bachelor's degree.

${ }^{19}$ This is confirmed by $\mathrm{t}$ tests on education level. Prior to the reform the difference between men and women is negative and statistically significant at the $5 \%$ level (even if the difference is of a small magnitude: 0.044), whereas following the reform there is no statistically significant difference between the education levels of men and women elected politicians.
} 
the elected pool. This does not happen for men, who display a lower percentage of high education individuals overall, with the opposite trend to women: that is to say that more high education men are in the elected pool (69\%) than in the non-elected pool $(65 \%)$. If the share of high education elected women had remained the same as that of the non-elected pool (i.e. $76 \%$ instead of $69 \%$ ) the total amount of high education elected politicians would have increased with respect to the pre-reform situation. ${ }^{20}$

By way of a sensitivity check of this finding that high education women are overrepresented in the non-elected as compared to the elected pool, we conduct the same analyses presented in Panels $\mathrm{C}$ and $\mathrm{D}$ of Table 7 but focusing on right wing parties (see the Appendix, Table A10). The idea here is that right wing parties traditionally cater to the professional classes and, as such, one can hypothesise that tertiary education would be less contradictory in terms of interest representation and formal skills than for other parties. Thus, if the finding persists amongst these parties, we can be more confident of the result. Indeed, we find the same pattern as we see for all parties, although it is less pronounced (a difference of $2 \%$ instead of $7 \%$ ) amongst these parties.

\footnotetext{
${ }^{20}$ In the Appendix, Section 5 we present results showing that there is no voter bias against women candidates that could explain this selection.
} 
Table 7. Qualification of Politicians, High and Low Education Categories Panel A: Women, Elected

\begin{tabular}{||l|l|l||}
\hline \hline & Pre & Post \\
\hline Overall Percentage & $12 \%$ & $19 \%$ \\
\hline Of which, High Edu. & $76 \%$ & $73 \%$ \\
\cline { 2 - 3 } Of which, Low Edu. & $24 \%$ & $27 \%$ \\
\hline
\end{tabular}

\begin{tabular}{||l|l|l||}
\hline \multicolumn{2}{|c|}{ Panel B: Men, Elected } \\
\hline \hline & Pre & Post \\
\hline Overall Percentage & $88 \%$ & $81 \%$ \\
\hline Of which, High Edu. & $74 \%$ & $72 \%$ \\
\cline { 2 - 3 } Of which, Low Edu. & $26 \%$ & $28 \%$ \\
\hline
\end{tabular}

Panel C: Women Non-Elected versus Elected, 2013

\begin{tabular}{||l|l|l||}
\hline \hline & Non-Elected Pool & Elected Pool \\
\hline Overall Percentage & $31 \%$ & $29 \%$ \\
\hline Of which, High Edu. & $76 \%$ & $69 \%$ \\
\cline { 2 - 3 } Of which, Low Edu. & $24 \%$ & $31 \%$ \\
\hline
\end{tabular}

Panel D: Men Non-Elected versus Elected, 2013

\begin{tabular}{||l|l|l||}
\hline \hline & Non-Elected Pool & Elected Pool \\
\hline Overall Percentage & $69 \%$ & $71 \%$ \\
\hline Of which, High Edu. & $65 \%$ & $69 \%$ \\
\cline { 2 - 3 } Of which, Low Edu. & $35 \%$ & $31 \%$ \\
\hline
\end{tabular}


We are aware that we use a simpler analysis for our second research question, with respect to the DiD used to answer our first research question, and, in this case, we are not able to establish a causal relationship. However, the data and figures presented clearly point to a difference in qualification. We also acknowledge that our results on education are not fully conclusive, since only data on the 2013 elections are available with information about candidates as well as elected deputies. Although it is difficult to quantify the substantive difference that an increased share of high qualification politicians in office makes, we have good reason to believe that this would lead to improved outcomes for the electorate. We know that for both the wider population (Dee, 2004; Milligan et al., 2004) and politicians (Besley et al., 2005), greater exposure to formal education is important for inculcating civic values and reducing opportunism. We also know that more educated leaders generate higher growth for their countries (Besley et al., 2011), indicating that a greater number of high qualification politicians would lead to welfare-increasing outcomes for citizens.

\section{Discussion and Conclusion}

In a within-country context, we present causal evidence that proportional electoral rules promote women's representation. We also present evidence that indicates that this increase in women's representation comes without a reduction of the qualification of politicians. In other words, proportional rules can be effective in attracting more women to politics and this may counterbalance the negative selection effect of proportional rules on qualification levels. Homing in on the 2013 election, we find a discrepancy between the qualification levels of elected and non-elected women, with non-elected women displaying significantly 
higher qualification levels than their elected counterparts. Given that we find no evidence of voter bias in our sample (Table A2, Appendix), party bias seems the most likely source of this qualification discrepancy amongst women.

This conclusion is in some ways unsurprising. Extensive evidence suggests that many Italian politicians do not see women as competitive, capable political agents, despite women politicians in Italy - as in many other countries - being as qualified (if not more so) as their male counterparts. Moreover, women politicians are less likely to be nominated as candidates by parties in majoritarian systems because they are perceived as less likely to be elected or to commit to a continuous, long-term political career (Norris and Lovenduski, 1995; Matland and Studlar, 1996; Hinojosa, 2009, 2012; Iversen and Rosenbluth, 2010). ${ }^{21}$ Women themselves come forward as candidate less frequently in majoritarian than proportional systems because they are averse to political exposure in political races (Kanthak and Woon, 2015), which is stronger in head-to-head majoritarian races than proportional systems. Women politicians' aversion to political exposure may itself be the result of their relative lack of political ambition, which in turn may be influenced by the cultural context: women with comparable credentials to their male counterparts are substantially less likely to perceive themselves as qualified to run for political office (Fox and Lawless, 2011, 2014) and to be recruited to run for public office by all types of political actors (Fox and Lawless, 2010; Lawless and Fox, 2010). That is not to say that women's aversion to personal exposure in political races is due to them

\footnotetext{
${ }^{21}$ The importance of electoral rules' impact on candidate nomination and selection processes cannot be overstated, such effects can even overshadow gender quotas (see Hinojosa, 2009) and gender quotas themselves can be difficult to implement for constitutional or cultural reasons.
} 
being less qualified. Our evidence of the higher qualification of women in both electoral systems is consistent with existing evidence (see Section 1) and the recent literature on gender quotas (Baltrunaite et al., 2014; Weeks and Baldez, 2015; Besley et al., 2017). ${ }^{22}$

Our results may be related to cultural factors and gender norms. In the Appendix (Section 6), we introduce a measure of gender culture and exploit its variation within Italian regions. We provide evidence that (controlling for macro region fixed effects) the more gender traditionalist regions of Italy are those that most increased their women's representation with the reform, but are also those with a stronger divergence between the qualification levels of non-elected and elected women politicians. ${ }^{23}$ This finding is in line with Besley et al. (2017)'s argument regarding mediocre male leaders and their desire to protect their own positions within the party at the cost of better qualified women politicians. The intuition is that in a more gender traditional setting, male political leaders are likely to be less accepting of the idea of a woman taking over their position and more likely to prize traditional gender traits over competence in women candidates, leading to a preference for lower qualification-type women candidates. It is also in line with the notion that parties are more likely to present balanced tickets under proportional rule (Matland, 2005; Hughes, 2011), with gender progressive parties likely to place highly qualified women in electable ranks (effectively wanting to elect strong women candidates), and more gender traditionalist parties wanting to signal that they have women on their

\footnotetext{
${ }^{22}$ These papers show that increases in the presence of women politicians (thanks to quotas) are related to increases in the overall qualification levels of politicians, because high-qualified women are elected in the place of low-qualified men.

${ }^{23}$ Our finding about the qualification levels of non-elected and elected women pertains to the 2013 national election only.
} 
lists, but placing less qualified women in electable ranks (to avoid the threat of strong women candidates to the leadership).

How generalisable are our results? Given that our estimates are drawn from data covering the entire Italian territory over several decades, we can be relatively confident of the internal validity of our findings. External validity in contexts outside of Italy is more difficult to evaluate, however. On the one hand, Italy is seen as an outlier amongst developed countries when it comes to gender equality. This suggests that our main results concerning the level of women's representation following the 2005 reform would mark a lower bound, in that we would expect gender inequality to have a dampening effect on the ability of the proportional electoral rule to increase women's representation. The divergence that we find in the qualification level of elected and candidate women politicians might instead represent an upper bound. On the other hand, Italy finds itself pretty squarely in the middle of worldwide rankings of gender equality (World Economic Forum, 2020) and is, thus, more representative of the vast majority of countries than outliers such as Iceland, Norway, Finland or Sweden.

With its status as a 'flawed democracy' (The Economist Intelligence Unit, 2019), Italy is also characterised by many of the same features as the majority of the world's democracies meaning that we could reasonably expect similar results to obtain in such contexts. ${ }^{24}$ We would also like to underscore that we examine a closed list PR system in this paper and it is unclear whether we would expect to see the same effects we uncover in an open list PR system. One of the key features of closed list PR systems when it comes to questions of representation is the fact that the party elite has much influence

\footnotetext{
${ }^{24}$ Flawed democracies and authoritarian regimes are the modal types of regimes across the globe at $32 \%$.
} 
on candidates' ballot list position, which can work to the detriment of minority groups (Bagues and Campa, 2021). In the Appendix (Section 8), we present an analysis that offers correlational evidence that high education men candidates are more likely than high education women candidates to be placed high on the ballot (in line with Bagues and Esteve-Volart (2010)), perhaps betraying fear on the part of the (male-dominated) party elite that such candidates would threaten their hegemony (Besley et al., 2017).

External validity is ultimately best addressed by comparing the results of several internally valid studies conducted in different contexts and at different points in time. More single-country assessments of the impact of electoral rules on women political representation are needed for a comparison with our results and we encourage future research to contribute to filling this gap. 


\section{References}

M. Bagues and P. Campa. Can gender quotas in candidate lists empower women? Evidence from a regression discontinuity design. Journal of Public Economics, 194(104315), 2021.

M. F. Bagues and B. Esteve-Volart. Can gender parity break the glass ceiling? Evidence from a repeated randomized experiment. The Review of Economic Studies, 77(4): 1301-1328, 2010.

A. Baltrunaite, P. Bello, A. Casarico, and P. Profeta. Gender quotas and the quality of politicians. Journal of Public Economics, 118:62-74, 2014.

T. Barnes and M. Holman. Taking diverse backgrounds into account in studies of political ambition and representation. Politics, Groups, and Identities, 7(4):829-841, 2019.

M. Becher and I. M. González. Electoral reform and trade-offs in representation. American Political Science Review, 113(3):694-709, 2019.

T. Besley and M. Reynal-Querol. Do democracies select more educated leaders? American Political Science Review, 105(3):552-566, 2011.

T. Besley, J. G. Montalvo, and M. Reynal-Querol. Do educated leaders matter? The Economic Journal, 121(554):F205-227, 2011.

T. J. Besley, R. Pande, and V. Rao. Political selection and the quality of government: evidence from South India. 2005.

T. J. Besley, O. Folke, T. Persson, and J. Rickne. Gender quotas and the crisis of the mediocre man: Theory and evidence from Sweden. American Economic Review, 107(8): $2204-2242,2017$. 
K. Bratton and L. Ray. Descriptive representation, policy outcomes, and municipal day-care coverage in Norway. American Journal of Political Science, 46(2):428-437, 2002.

M. P. Buitrago and M. P. Aroca. Effects of institutional reforms on women's representation in Colombia, 1960-2014. Latin American Politics and Society, 59(2):103-121, 2017.

J. Carey and M. S. Shugart. Incentives to cultivate a personal vote: A rank ordering of electoral formulas. Electoral studies, 14(4):417-439, 1995.

N. Carnes and N. Lupu. What good is a college degree? Education and leader quality reconsidered. The Journal of Politics, 78(1):35-49, 2016.

M. Castiglioni. Ideological and non-ideological camp effects on local resource misallocation. MPSA Annual Conference, 2020.

F. Cavalcanti, G. Daniele, and S. Galletta. Popularity shocks and political selection. Journal of Public Economics, 165:201-216, 2018.

J. Cayer and L. Sigelman. Minorities and women in state and local government: 1973-1975. Public Administration Review, 40(5):443-450, 1980.

T. S. Dee. Are there civic returns to education? Journal of Public Economics, 88(9-10): $1697-1720,2004$.

K. Dolan. Gender stereotypes, candidate evaluations, and voting for women candidates: what really matters? Political Research Quarterly, 67(1):96-107, 2014.

K. Dolan. Voting for women: How the public evaluates women candidates. Routledge, 2018. 
K. Dolan and T. Lynch. The impact of gender stereotypes on voting for women candidates by level and type of office. Politics \& Gender, 12(3):573-595, 2016.

O. Folke and J. Rickne. Electoral competition and gender differences in political careers. Quarterly Journal of Political Science, 11(1):59-102, 2016.

R. Fox and J. Lawless. If only they'd ask: gender, recruitment, and political ambition. The Journal of Politics, 72(2):310-326, 2010.

R. Fox and J. Lawless. Gendered perceptions and political candidacies: a central barrier to women's equality in electoral politics. American Journal of Political Science, 55(1): 59-73, 2011.

R. Fox and J. Lawless. Uncovering the origins of the gender gap in political ambition. American Political Science Review, 108(3):499-519, 2014.

S. Franceschet and J. M. Piscopo. Equality, democracy, and the broadening and deepening of gender quotas. Politics \& Gender, 9(3):310-316, 2013.

G. Fréchette, F. Maniquet, and M. Morelli. Incumbents' interests and gender quotas. American Journal of Political Science, 52(4):891-909, 2008.

S. Gagliarducci, T. Nannicini, and P. Naticchioni. Electoral rules and politicians' behavior: a micro test. American Economic Journal: Economic Policy, 3(3):144-174, 2011.

V. Galasso and T. Nannicini. Competing on good politicians. American Political Science Review, 105(1):79-99, 2011.

V. Galasso and T. Nannicini. So closed: political selection in proportional systems. European Journal of Political Economy, 40(B):260-273, 2015. 
S. Golder, L. Stephenson, K. Van der Straeten, A. Blais, D. Bol, P. Harfst, and J.-F. Laslier. Votes for women: electoral systems and support for female candidates. Politics Ef Gender, 13(1):107-131, 2017.

D. Hangartner, E. Dinas, M. Marbach, K. Matakos, and D. Xefteris. Does exposure to the refugee crisis make natives more hostile? American Political Science Review, 113 (2):442-455, 2019.

D. Hayes and J. Lawless. Women on the run: gender, media, and political campaigns in a polarized era. Cambridge University Press, 2016.

Z. Hessami and T. Baskaran. Competitively elected women as policy makers. 2019.

Z. Hessami and M. Lopes da Fonseca. Female political representation and substantive effects on policies: a literature review. European Journal of Political Economy, 63: 101896, 2020.

M. Hinojosa. "Whatever the party asks of me": women's political representation in Chile's Unión Demócrata Independiente. Politics \& Gender, 5(3):377-407, 2009.

M. Hinojosa. Selecting women, electing women: political representation and candidate selection in Latin America. Temple University Press, 2012.

M. Hughes. Intersectionality, quotas, and minority women's political representation worldwide. American Political Science Review, 105(3):604-620, 2011.

Inter-Parliamentary Union. Women in Parliament in 2016: the Year in Review. http: //ow. 1y/OSRJ50ykpGb, 2016. 
Inter-Parliamentary Union. Women in national parliaments. http://ow . ly/Byj750ykq2b, 2017.

T. Iversen and F. M. Rosenbluth. Women, work, and politics: the political economy of gender inequality. Yale University Press, 2010.

G. Jacobson. Strategic politicians and the dynamics of US house elections, 1946-86. American Political Science Review, 83(3):773-793, 1989.

K. Kanthak and J. Woon. Women don't run? Election aversion and candidate entry. American Journal of Political Science, 59(3):595-612, 2015.

J. King. Single-member districts and the representation of women in American state legislatures: the effects of electoral system change. State Politics $\&$ Policy Quarterly, 2 (2):161-175, 2002.

M. C. Kittilson and L. Schwindt-Bayer. The gendered effects of electoral institutions: political engagement and participation. Oxford University Press, 2012.

S. Larserud and R. Taphorn. Designing for equality: women's quotas and women's political participation. Development, 50(1):36-42, 2007.

J. Lawless and R. Fox. It still takes a candidate: why women don't run for office. Cambridge University Press, 2010.

T. Le Barbanchon and J. Sauvagnat. Voter bias and women in politics. Journal of the European Economic Association, forthcoming.

R. Matland. Enhancing women's political participation: legislative recruitment and electoral systems. Women in parliament: beyond numbers, 2:93-111, 2005. 
R. Matland and D. Studlar. The Contagion of Women Candidates in Single-Member District and Proportional Representation Electoral Systems: Canada and Norway. The Journal of Politics, 58(3):707-733, 1996.

K. Milligan, E. Moretti, and P. Oreopoulos. Does education improve citizenship? Evidence from the United States and the United Kingdom. Journal of Public Economics, 88 (9-10):1667-1695, 2004.

R. Murray. Second among unequals? A study of whether France's "quota women" are up to the job. Politics \& Gender, 6(1):93-118, 2010.

R. Murray. Parity and legislative competence in France. The Impact of Gender Quotas, 2012.

R. Murray. What makes a good politician? Reassessing the criteria used for political recruitment. Politics \& Gender, 11(4):770-776, 2015.

P. Norris. Women's legislative participation in Western Europe. West European Politics, 8(4):90-101, 1985.

P. Norris. The impact of electoral reform on women's representation. Acta politica, 41(2): 197-213, 2006.

P. Norris and J. Lovenduski. Gender and party politics. Sage Publications, 1993.

P. Norris and J. Lovenduski. Political recruitment: gender, race and class in the British Parliament. Cambridge University Press, 1995.

D. O'Brien and J. Rickne. Gender quotas and women's political leadership. American Political Science Review, 110(1):112-126, 2016. 
OECD. Women in national parliaments. https://data.oecd.org/inequality/womenin-politics.htm, 2019.

T. O'Grady. How do economic circumstances determine preferences? Evidence from long-run panel data. British Journal of Political Science, 49(4):1381-1406, 2019.

P. Profeta and E. F. Woodhouse. Replication data and code for 'Electoral rules, women's representation and the qualification of politicians'. https://doi.org/10.7910/DVN/ VMPZIX, 2021.

A. Roberts, J. Seawright, and J. Cyr. Do electoral laws affect women's representation? Comparative Political Studies, 46(12):1555-1581, 2013.

W. Rule. Why women don't run: the critical contextual factors in women's legislative recruitment. Western Political Quarterly, 34(1):60-77, 1981.

W. Rule. Electoral systems, contextual factors and women's opportunity for election to parliament in twenty-three democracies. Western Political Quarterly, 40(3):477-498, 1987.

W. Rule. Women's underrepresentation and electoral systems. Political Science \&f Politics, 27(4):689-692, 1994.

W. Rule and M. Shugart. The preference vote and the election of women. http: //ow. 1y/j6Bk50ykpwK, 1995.

W. Rule and J. F. Zimmerman. Electoral systems in comparative perspective: their impact on women and minorities. Greenwood Publishing Group, 1994. 
M. S. Shugart. Minorities represented and unrepresented. In W. Rule and J. F. Zimmerman, editors, Electoral systems in comparative perspective: their impact on women and minorities. Greenwood Publishing Group, Westport, CT, 1994.

M. S. Shugart, M. E. Valdini, and K. Suominen. Looking for locals: voter information demands and personal vote-earning attributes of legislators under proportional representation. American Journal of Political Science, 49(2):437-449, 2005.

F. Thames. Understanding the impact of electoral systems on women's representation. Politics \& Gender, 13(3):379-404, 2017.

The Economist Intelligence Unit. Democracy Index 2019. http://www.eiu.com, 2019.

M. E. Valdini. Electoral institutions and the manifestation of bias: the effect of the personal vote on the representation of women. Politics $\&$ Gender, 9(1):76-92, 2013.

R. Vengroff, Z. Nyiri, and M. Fugiero. Electoral system and gender representation in sub-national legislatures: is there a national-sub-national gender gap? Political Research Quarterly, 56(2):163-173, 2003.

A. C. Weeks and L. Baldez. Quotas and qualifications: the impact of gender quota laws on the qualifications of legislators in the Italian parliament. European Political Science Review, 7(1):119-144, 2015.

World Economic Forum. Global gender gap report 2020. http://www3. weforum.org/ docs/WEF_GGGR_2020.pdf, 2020. 